\title{
STK36 wt Allele
}

National Cancer Institute

\section{Source}

National Cancer Institute. STK36 wt Allele. NCI Thesaurus. Code C150325.

Human ST K36 wild-type allele is located in the vicinity of 2 q35 and is approximately $31 \mathrm{~kb}$ in length. This allele, which encodes serine/threonine-protein kinase 36 protein plays a role in the modulation of GLI family transcription factor activity. 